\title{
Nanocomposite Electrolyte for PEMFC Application
}

\author{
Mahreni' $^{1}$, A.B. Mohamad ${ }^{2}$, A.A.H. Khadum² and W.R.W. Daud ${ }^{2}$ \\ "Universitas Pembangunan Nasional "Veteran" Yogyakarta, \\ ¿Universiti Kebangsaan Malaysia, \\ ${ }^{1}$ Indonesia \\ ${ }^{2}$ Malaysia
}

\section{Introduction}

Fuel demand is predicted to increase by $6.3 \%$ by each year, in particular the motor vehicle sector where is expected to increase by $41 \%$ per year. Gas generated from burning fossil fuels produce emission that cause global warming effect as perceived from the parameters such as (i) increase in global temperature, (ii) global climate change phenomena and (iii) the melting of the ice caps.

One effort to overcome the effects of global warming is by replacing fossil fuels with hydrogen fuel. Hydrogen fuel and fuel cell technology had been proven able to minimise the production of toxic flue gases produced by combustion of fossil fuels. Hydrogen fuel is one of the first order candidate to replace fossil fuels because the combustion of hydrogen produce only electricity and water without the emission on of $\mathrm{CO}_{2}, \mathrm{NO}_{\mathrm{x}}, \mathrm{SO}_{\mathrm{x}}$ and volatile organic compounds. In addition, hydrogen as a raw material can be renewed and could be harvested from multiple processing methods.

Some countries have tried to produce renewable fuels with a large capacity as would be done by China by 2020 where it is expected to produce $20 \%$ of the renewable energy while New Zealand at 70\%, Brazil has been producing bio-fuels on large scale and U.S. bio-fuel have been supplied from corn. U.S. and Japan have reserved the hydrogen as a substitute for fossil fuel. It is estimated that hydrogen fuel to be economical by 2050 .

Fuel cell technology will be one of the appropriate technologies to convert hydrogen into electric energy when hydrogen is continuously supplied. Fuel cell would be able to replace fossil-fuelled engine with higher efficiency and expected to produce minimum or no pollutants and have been developed in order to reduce the problems of green house gas effect produced through the combustion of fossil fuel.

\subsection{Proton Exchange Membrane Fuel Cell (PEMFC)}

Fuel cell is a power generator that convert hydrogen and oxygen via electrochemical reaction into electrical energy with, the thermodynamic efficiency as high as about $60 \%$, comparing to the conventional engine which is only $30 \%$ efficiency. Electric power is resulted from electrochemical oxidation reaction of hydrogen molecule at an anode surface and resulted in the movemet of the electron $\left(\mathrm{e}^{-}\right)$and proton $\left(\mathrm{H}^{+}\right)$. In addition, reduction of 
oxygen molecules takes place at cathode surface and produce oxygen ion $\left(\mathrm{O}^{2-}\right)$. Protons from the anode are delivered to the cathode through the electrolyt membrane when electron moves through the external circuit left the system to be used as an electric power. The electrons then reenter the cathode surface. Where, oxygen ions, electrons and protons will electrochemically react to produce water molecules.

The reactions taking place at the cathode and anode surfaces are indicated by reaction mechanisms in equation (1) to (3) (Gyenge, 2005). The result of the power conversion is water which make PEMFC device an environmentally friendly electric power generator (Kong et al., 2002).

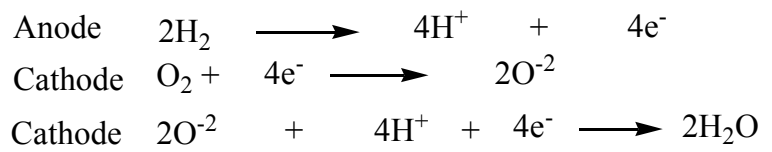

Among the different type of fuel cells, PEMFC is the most interesting to researchers and industries as the power device in the automotive. Due to this cell can be adjusted with the size of required power, and can be used for various power generator devices.

\subsection{Basic component of proton exchange membrane fuel cell (PEMFC)}

PEMFC components consist of two electrodes, i.e. anode and cathode, separated by the electrolyte membrane. The anode is supported by anode gas diffusion layer (GDLA), while the cathode is supported by cathode gas diffusion layer (GDLC). This cell is sandwiched by the bipolar pate and current collector, end plates and external circuit to connect the anode and the cathode (Mahreni, 2009). The single cell schematic configuration of PEMFC, is presented in Fig. 1 (a) \& (b) bellow.
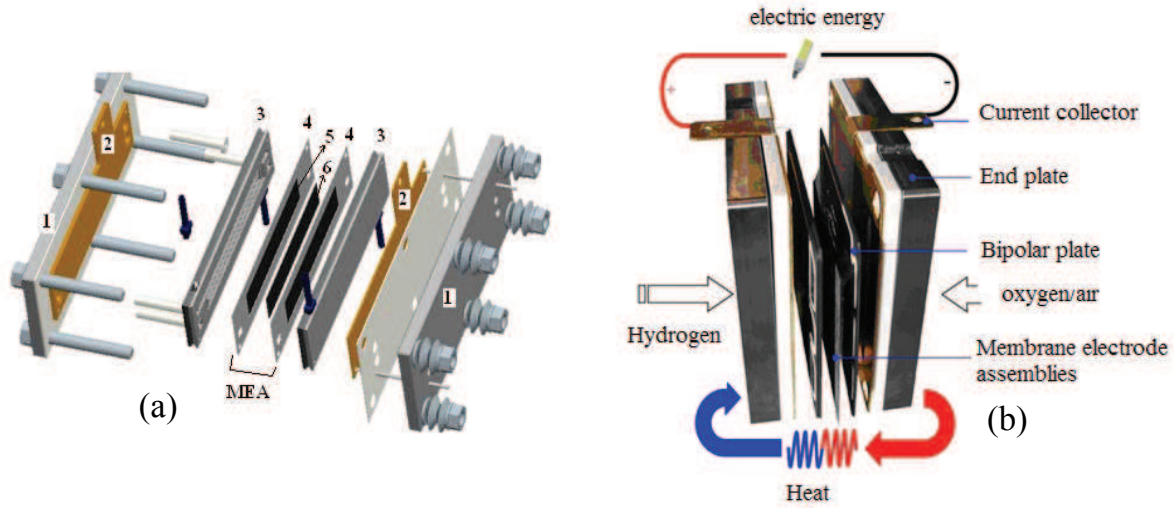

Fig. 1. Schematic PEMFC component (a) and schematic operation (b) of the PEMFC system. (1) End plate (EP), (2) Current collector (CC), (3) Bipolar plate (BP), (4) Gas diffusion layer (GDL), (5) Electrode, (6) Proton electrolyte membrane (PEM). The schematic of PEMFC power generation is shown in Fig. 1 (b). (http://id.images.search.yahoo.com/search/images)

The function of GDL is to support the catalyst. As well as the gas distributor via the porous layer as a way the water molecule would exit from the system. It also acts as electron conductor through the carbon particles. The microstructure of the GDL greatly affect the 
fuel cell performance because this is the site that establish the electron transfer resistant from and to the electrolyte surfaces (Park et al., 2004).

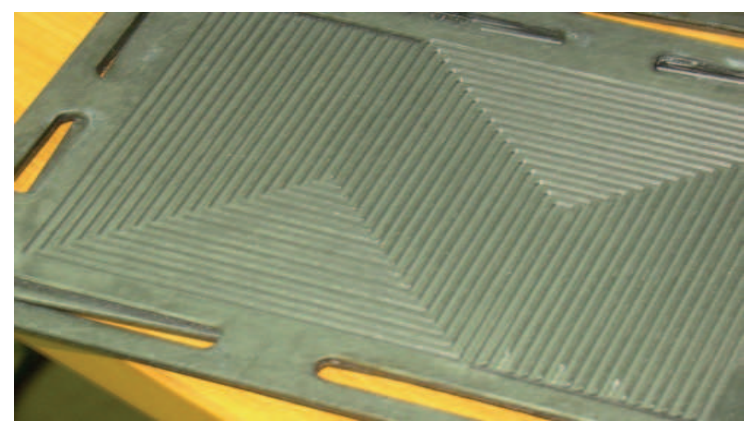

Fig. 2. An example of a plate.

An example of bipolar plate in Fig. 2 there are four main functions ofthe bipolar plate namely (i) as a flow field of fuel, air and coolant, (ii) as a separating cell unit from other cell unit in a stack, (iii) as a conductor of current from a cell unit in the stack and as (iv) as a support of a series of membrane-electrode assemblies (MEA) (Lee et al., 2007).

Catalyst layer is made up of $\mathrm{Pt} / \mathrm{C}$ which is used as the electrode to accelerate the reaction of hydrogen oxidation on the anode surface and oxygen reduction reaction on the cathode surface.

The improvement of PEMFC had been carried out to minimize catalyst concentration and increasing catalyst resistance to $\mathrm{CO}$. The efforts have been done of reducing the catalyst particles to nano size in order to increase the surface active area of the catalyst. The other attemt that have been done to increase the resistancy of the catalyst to the $\mathrm{CO}$ poisoning is increase the operating temperature of PEMFC. At higher temperature $\mathrm{CO}$ molecules less adsorb to the catalyst surface make the life time of the catakyst is increase to.

Perfluorosulfonic acid (PFSA) membrane, such as Nafion, is the polyelectrolyte most widely used in PEMFCs because it exhibits excellent inherent properties of up to about $90^{\circ} \mathrm{C}$ in terms of the proton conductivity, mechanical stability and chemical inertia. Smitha et al., 2005 have reported the disadvantages of Nafion membrane, as follow (i) the price is very expensive $\left(\$ 700 / \mathrm{m}^{2}\right)$, (ii) requires a humidification device, and (iii) limited usage it a low temperature. The PEMFC development in future needs electrolyte membranes having characteristics including (i) high conductivity to support a fast current by minimizing a potential loss caused by internal resistance and moreover caused by $\mathrm{H}^{+}$ion transfer resistance through the membrane, (ii) isolator for electron transfer, (iii) adequate mechanical and chemical resistance and electrochemically stable under operating condition, (iv) impermeable against oxygen and hydrogen, and (v) cheap.

Power resulted by a fuel cell is known from resulted current density and voltage. This cell performance is influenced by the electrochemical reaction rate in anode and cathode. The electrochemical reaction rate is influenced by many factors, among them are the thermodynamics, kinetic, ion and mass transfer (Gynge, 2006).

The temperature effect on thermodynamic and kinetic parameters can be explained by reaction parameters involved in the power generation, where (i) standard exchange current density $\left(i_{0}\right)$, (ii) equilibrium voltage $\left(E_{\text {rev }}\right)$, (iii) Tafel slope (b) and (iv) electron transfer rate coefficient (a). 
Standard exchange current density, $i_{0}$ is a basic property of an electrode which can be defined as oxidation or reduction rate at the equilibrium condition which is represented as current. The current at the equilibrium condition states that oxidation and reduction rates are in the equilibrium. There is no theory that can be used to calculate standard current density at a certain system and must be calculated by experiment.

Value of standard exchange current density depends on some parameters related to electrode properties, i.e. type of catalyst metal, characteristic of catalyst surface and pollutant concentration at the catalyst surface. Other than electrode characteristic, temperature is also greatly influence to the value of standard exchange current density. Standard exchange current density $\left(i_{0}\right)$ is increasingly when the temperature increased. Beatti et. al. reported that the value $i_{0}$ of Pt/Nafion 117 increases from 2,8x10-10 A/ $\mathrm{cm}^{2}$ at the temperature of $303 \mathrm{~K}$ to $3,71 \times 10^{-9} \mathrm{~A} / \mathrm{cm}^{2}$ at the temperature of $343 \mathrm{~K}$. The value of $i_{0}$ at $\mathrm{Pt}$ membrane surface other than Nafion (BAM 407) is reported increased when the temperature increases from $8,80 \times 10^{-11} \mathrm{~A} / \mathrm{cm}^{2}$ at $303 \mathrm{~K}$ to $4,38 \times 10^{-10} \mathrm{~A} / \mathrm{cm}^{2}$ at $343 \mathrm{~K}$. Increasing the value of $i_{0}$ at a higher temperature shows that the catalyst activity getting increase.

Thermodynamic equilibrium voltage $\left(E_{\text {rev }}\right)$ is the maximum voltage which may be resulted when $1 \mathrm{~mol}$ of water is resulted by $1 / 2 \mathrm{~mol}$ of oxygen and $1 \mathrm{~mol}$ of hydrogen at a certain condition. Equilibrium voltage is influenced by temperature and partial pressure of hydrogen and oxygen at the catalyst surface. Equation (4) shows $V_{\text {thermodynamic }} \mathrm{H}_{2} / \mathrm{O}_{2}=\mathrm{V}_{\text {cell, }}$, maximum i.e. the maximum voltage or equilibrium voltage at standard condition (pressure of 1 atmosphere, temperature of $25^{\circ} \mathrm{C}$ and reactant activity $=1$ ).

$$
\mathrm{V}_{\text {cell, maximum }}=\mathrm{E}_{\mathrm{c}}-\mathrm{E}_{\mathrm{a}}=1.229 \text { volt }
$$

Generally, the reaction takes place in a non standard condition. Cell voltage $\left(\mathrm{V}_{\text {cell }}\right)$ at a non standard condition is calculated based on Nerst equantion. The expanded Nerst equation is a model equation used in the PEMFC system by Gyenge (2005) as in equation (5).

$$
E=E^{0}+\frac{R T}{2 F} \ln \left(\frac{P_{\mathrm{H}_{2} P_{\mathrm{O}_{2}}^{0.5}}}{P_{\mathrm{H}_{2} \mathrm{O}}}\right)
$$

$E$ and $E^{0}, \mathrm{R}, \mathrm{T}, \mathrm{F}, P_{\mathrm{H}_{2}}, P_{\mathrm{O}_{2}}, P_{\mathrm{H}_{2} \mathrm{O}}$ respectively are cell potential and open circuit potential, gas constant, temperature, faraday constant, partial pressure of hydrogen, oxygen and water. Resulted cell voltage always smaller than equilibrium voltage. The decreasing voltage from equilibrium voltage is caused by polarization. Polarization taken place in the PEMC comprises polarization of catalyst activity, polarization of electron and proton transfer, and polarization of mass transfer. Equation of polarization model can be expressed as equation (6) (Baschuk et. al. 2000).

$$
E=E_{0}+b \log i_{0}-b \log i-R i-\gamma \exp (\omega i)
$$

The resulted power of a cell is $P$ as in equation (7).

$$
P=E I
$$

where $E, E_{0}, i, b, R, \gamma, \omega, P$ respectively are cell voltage $\left(\mathrm{V}_{\mathrm{sel}}\right)$, open circuit voltage $\left(\mathrm{V}_{\mathrm{ocv}}\right)$, current density $(i)$, Tafel slope, electron and proton transfer resistance $(R)$, mass transfer resistance $(\gamma)$, fitting parameter $(\omega)$ and power $(P)$. The open circuit voltage is a electrical 
potential difference between cathode and anode when there is no electric current. The Tafel coefficient depends on temperature empirically may be expressed as equation (8).

$$
b=\frac{-2.3 R T}{\alpha n F}
$$

Where $\mathrm{F}, \mathrm{R}, \alpha$ are respectively Faraday constant, gas constant and constant of electron transfer in the electrode, and $n$ is the number of electrons involved in electrochemical reaction. Equation (8) shows that Tafel constant is influenced by temperature, where as higher the temperature the higher the Tafel constant (Berger 1968), (Zhang et. al. 2006).

It is probably concluded by the researchers that the Tafel slope and oxygen reduction reaction will increase when the temperature increases at the range of a low current density. At a high current density, the Tafel curve does not depend on the temperature. Another advantage which can be reached at a high temperature condition is that rate of $\mathrm{CO}$ absorption greatly slower than the rate of hydrogen, so the limit $\mathrm{CO}$ content in the fuel may reach 100 ppm (Zhang et. al. 2006; Xu et. al. 2006).

Principally, the hydrogen resulted from the reforming process that use as the fuel for PEMFC today, generally has high CO content, have impurities about $200 \mathrm{ppm}$ which requires purification device before hydrogen can be used as a fuel. To make the resulted hydrogen from this reforming process able to be used as a fuel directly without $\mathrm{CO}$ purification, the operating temperature has to be increased (Yang et al., 2001) up to $130{ }^{\circ} \mathrm{C}$, where platinum catalyst may resist against CO content up to $1000 \mathrm{ppm}$. Hence the choice to increase the cell performance of the fuel cell in the future is to increase the operating temperature.

\subsection{The problem statement}

The obstacle of high temperature operation is the membrane shrinking, that would lose the mechanical strength and increase hydrogen and oxygen permeability. The hydrogen and oxygen penetrated through the membrane and co exist at the catalyst-membrane surface create exothermic reaction thus increasing the temperature on one side or a hot spot at the membrane surface. The temperature in that hot spot location will increased that could easily membrane damage. The shrinking of Nafion membrane or (PFSA) group, would normally takes place at high temperature and low relative humidity condition which is accompanied by decreasing membrane conductivity to proton. The Nafion 115 conductivity decreased by decreasing water activity at the temperature between 80 to $140{ }^{\circ} \mathrm{C}$ (Yang et al., 2004). The research is still undergone in order to PEMFC may compete the existing machine potentials. Among the researches which had been carried out in commercializing PEMFC include (i) developing anode catalyst which resisted to $\mathrm{CO}$, for example using metal alloy such as $\mathrm{Pt}-\mathrm{Ru} / \mathrm{C}, \mathrm{Pt}-\mathrm{Ru} / \mathrm{C}$ (nanotube), in order to be used with CO content in the hydrogen reach $>50 \mathrm{ppm}$, (ii) using other type of membrane that cheaper than Nafion membrane or modifies the Nafion membrane that has high conductivity at low relative humidity (Mahreni et al., 2009).

\subsection{Nafion membrane}

Perfluorosulfonic acid (PFSA) membranes (e.g. Nafion) is not suitable used as electrolyte of high temperature and low relative humidity PEMFC due to anisotropic membrane swelling that occurs when the membrane is pressed between the electrodes, which provoke 
irreversible conductivity decay (Alberti et al., 2007). The possibility to modify physical and chemical properties of a polymer by dispersing inorganic nanoparticles in the polymeric matrix (Ramani et al., 2005; Adjemian et al., 2002) encourages the development of proton conducting composite membranes suitable for PEMFCs that could work at temperatures above $100^{\circ} \mathrm{C}$ and low relative humidity.

Therefore, the research focuses on membrane performance improvement and suitable as electrolyte of high temperatures and low humidity PEMFC.

\subsubsection{Understanding the structure of the Nafion membrane}

The structure of Nafion $\left(\mathrm{C}_{7} \mathrm{HF}_{13} \mathrm{O}_{5} \mathrm{SC}_{2} \mathrm{~F}_{4}\right)$ membrane is shown in Fig. 3 and 4 . These figure shows the Nafion structure and Nafion cluster respectively (Smitha et al., 2005; Hamnett 2003).

Nafion is a poly electrolyte composed of tetrafluoroethylene $\left(\mathrm{CF}_{2}-\mathrm{CF}_{2}\right)(\mathrm{TFE})$ segment which is the main chain of the polymer and perfluorosulphonic vinyl ether (PSVE) $\left(\left(\mathrm{CF}_{2}-\mathrm{CF}\left(\mathrm{OCF}_{2}-\right.\right.\right.$ $\left.\mathrm{CF}\left(\mathrm{CF}_{3}\right)-\mathrm{CF}_{2}-\mathrm{CF}_{2}-\mathrm{SO}_{3} \mathrm{H}\right)$ as chain side. The backbone of polymer is non-polar or hydrophobic which is the fluorocarbon chain that provides the mechanical strength and heat resistance properties to Nafion. The side chain of the Nafion polymer that its end is sulphonic group $\left(\mathrm{SO}_{3} \mathrm{H}\right)$, is polar (hydrophylic) and could transfer protons. The amount of $x$ for Nafion membrane is 6.5 (Klein et al., 2005).

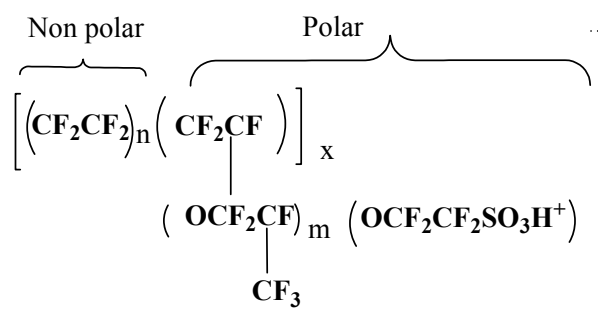

Fig. 3. Chemical structure of Nafion membrane.

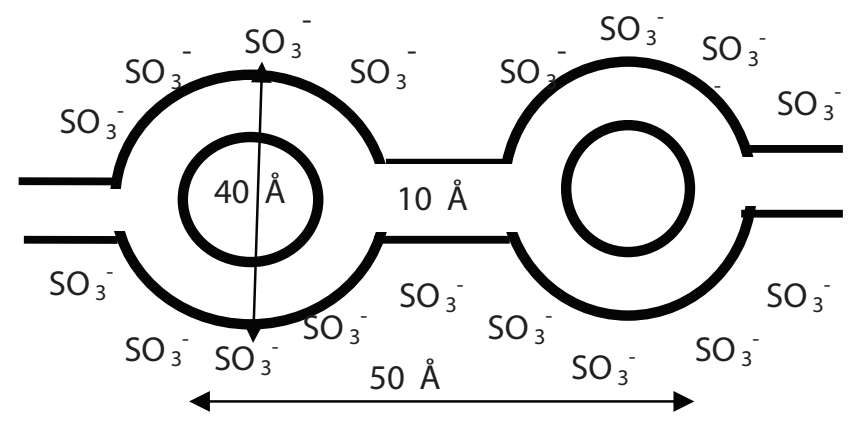

Fig. 4. Nafion cluster (Hamnett, 2003).

Micro structure of Nafion membrane consists of crystalline and ionic phase. Ionic group is $\mathrm{SO}_{3} \mathrm{H}$ - functional group which is surrounded by primary water molecules. Some ionic group with the size of (2 to 4$) \mathrm{nm}$ form a one unit cluster. Between one cluster and other clusters are connected by a narrow channel, which has size of $1 \mathrm{~nm}$. Ionic group and the channels 
sizes depend on the amount of existing water in the membrane. The size of the cluster and channel comparable with water content in the membrane (Jiang Yu Li \& Sia Nemat-Nasser. 2000).

The existing water molecules and the electro osmotic drag in the membrane will increase proton mobility and the protons $\left(\mathrm{H}^{+}\right)$of sulphonate group $\left(\mathrm{SO}_{3} \mathrm{H}\right)$ will escape. Protons that have been separated from the sulphonate group, may coalesce with $\mathrm{H}_{2} \mathrm{O}$ molecules in the form of hydronium $\left(\mathrm{H}_{3} \mathrm{O}^{+}\right)$and oxonium $\left(\mathrm{H}_{2} \mathrm{O}_{5}{ }^{+}\right)$ions are transferred through the membrane.

The water that fills Nafion polymer pores around the hydrophilic section is recognized as the primary water. The primary water consists of three molecules of water for every sulphonate group. If the amount of primary water has been fulfilled, the excessive water fills the main chain and side chain of pore size (4 to 10) $\mathrm{nm}$. The water that fills these pores is called the secondary water. If the water content in the membrane is adequate for primary hydration, the proton transfer through the membrane is equal to the proton diffusion rate through water molecules. It can be concluded that the proton conductivity is proportional to the water molecules content in the membrane. Therefore, the higher the water content the higher the proton conductivity and vice versa.

Another characteristic that determines the membrane conductivity is water uptake rate (WUR). Water uptake rate (WUR) can be defined as the maximum water content that can be absorbed by the membrane on the certain temperature and relative humidity condition. The water uptake rate is associated with membrane permeability properties against polar solvents for example water or alcohol. The higher the WUR is the higher the conductivity and vice versa (Mahreni et al., 2009).

Considering that the water content in the membrane is very critical determining proton conductivity. So the water control in hydrogen fuel cell requires special attention because water is continuously produced by the reaction at the cathode. Water is also carried by hydrogen and oxygen from the outside of the cell as a humidifier to hydrogen and oxygen.

\subsubsection{Model of proton transfer in the Nafion membrane}

Two models that have been proposed and would be able to explain the mechanism of proton transfer through Nafion membrane is Kreur, 1996 describing the vehicle theory and second model presented by Grotthuss who proposed the theory of protons hopping (Ramani et al., 2005).

The vehicle model assumes that the moving protons will always be accompanied by water molecules in the form hydronium $\left(\mathrm{H}_{3} \mathrm{O}^{+}\right)$or Jundel ions $\left(\mathrm{H}_{2} \mathrm{O}_{5}{ }^{+}\right)$and eigen ions $\left(\mathrm{H}_{9} \mathrm{O}_{4}{ }^{+}\right)$ (Pivovar, 2006). Hydronium molecules diffuses from one ionic group to the other ion group in the membrane polymer matrix. Transfer of hydronium ion caused by the concentration difference between ionic group. Diffusion of the hydronium ion causes the back diffusion of water molecules occure in the opposite direction with the direction of hydronium ion diffusion. Furthermore, water molecules otomatically may bind a proton to form hydronium ion again, and by the substitute of protons can be through the membrane polymer matrix continuously.

Proton transfer rate is in line with hydronium ion transfer rate through a group of water molecules. The ion transfer illustrated as a proton hopping between the ionic groups $\left(\mathrm{SO}_{3} \mathrm{H}\right)$ can be presented in Fig. 5 and 6 below.

Proton hopping model illustrates that the water molecules are not moving (still) remains in place. Proton hops from one ionic group $\left(\mathrm{SO}_{3} \mathrm{H}\right)$ to the other ionic groups through the water 
media which remained in place. Proton hops caused by the original arrangement (reorientation) of sulphonate group from asymmetry form to symmetry form. In hydrated conditions, the change of asymmetry to symmetry occurred faster. This condition causes the activation energy of proton hopping becomes lessen and causing the transfer rate of the proton faster. If the water content is low then the time required by a sulphonate group to return to symmetrical form is slower and proton transfer to be slow (Ramani et al., 2004).

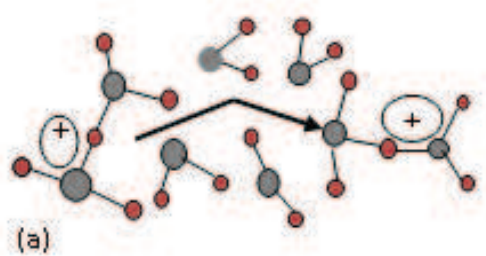

(a)

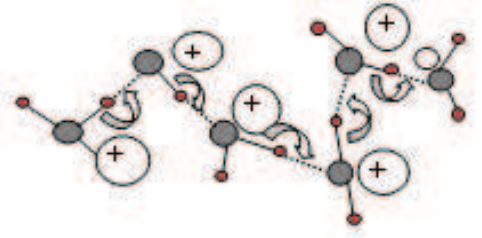

(b)

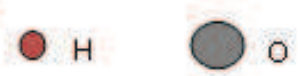

Fig. 5. Mechanism of proton transfer in the Nafion membrane in accordance with (a) the vehicle theory and (b) proton hopping theory.

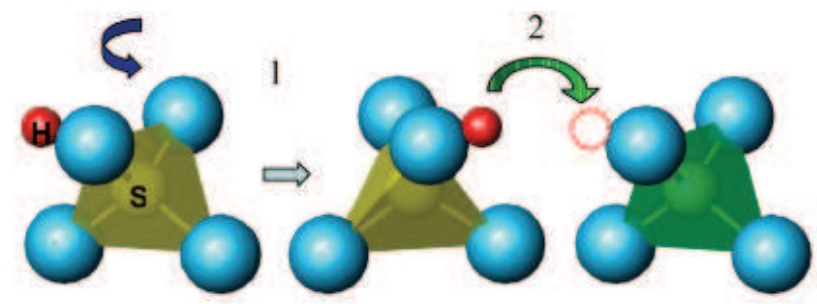

Fig. 6. Protons hopping in the Nafion membrane.

High water content in the membrane also causes the size of the channel that connects a group of ionic and other ionic groups will get larger and encourage water diffusion more rapid. In accordance with the vehicle theory which explains that when a water diffusion is fast, the transfer of protons also fast.

\section{Composite electrolyte membrane based on hydrocarbon-inorganic materials}

Sulphonated hydrocarbon polymers have been studied to replace Nafion by reason of cheaper and higher heat resistance compared to Nafion membrane. Hydrocarbon components that have been used are sulphonated polysolphone (PSF), polyetersulphone (PES), polyetereterketone (PEEK) (Ayad et al., 2005), poly(imides) (PI) and poly (4penoxibenzoil-1 ,4-phenilene) (PPBP). Hydrocarbon membrane is stable at high temperature. Aromatic polyimides has been synthesized by (Genies et al., 2001) and shows a high conductivity but the structure of main chain of the polymer easily be hydrolyzed. Sulphonated polybenziimidazole (PBI) has been produced by several researchers and has been used as an electrolyte in the PEMFC. The grafted polybenziimidazol (PBI) with sulphopropil unit shows conductivity of $10^{-3} \mathrm{~S} \mathrm{~cm}^{-1}$ at the temperature region of (20 to 140) ${ }^{\circ} \mathrm{C}$ and better than Nafion at the same condition, but if the PEMFC operating temperature is 
increased up to temperatures of above $100{ }^{\circ} \mathrm{C}$, the membrane loses the sulphonate acid group because of hydrolysis reaction.

The weakness of hydrocarbon electrolyte membrane is the main chain of sulphonated hydrocarbon polymer that less hydrophobic and the sulphonated acid group less acidic and more polar. Therefore, the water molecules inside the membrane is dispersed in the polymer nanostructure and causes at the saturated humidity $(100 \% \mathrm{RH})$ the water diffusion rate of Nafion membrane is higher than the hydrocarbon membrane. The higher water diffusion rate of Nafion at $100 \% \mathrm{RH}$ has meaning conductivity of the Nafion membrane at saturated condition higher than hydrocarbon membrane.

\section{Modified PFSA membrane}

PFSA membrane modification is lead to produce membrane that has high stability at high temperatures (80 to 120$)^{\circ} \mathrm{C}$ and at low humidity.

The main objective of the membrane modification is to make the membrane could to transfer the proton without water molecules or make the membrane as self humidifier membrane by introduce the dopan component that could transfer proton via proton hopping mechanism. This effort was less successful, so effort to improve the Nafion membrane is still continue with the target to improve water management by adding a hygroscopic component and high conductivity such as silica and inorganic materials. This effort is quite successful because by entering silica component and or strong acid can reduce the membrane thickness and the membrane is stable at low humidity, and easily control the water content in the membrane (Adjemian et al., 2002). The resulting composite membrane can absorb water more than the pure Nafion.

\section{Composite membrane of Nafion-SiO ${ }_{2}-\mathrm{HPA}$}

Organic-inorganic composite membrane consist of organic membrane of Nafion and inorganic component of $\mathrm{SiO}_{2}-\mathrm{HPA}, \mathrm{SiO}_{2}-\mathrm{SiWA}, \mathrm{SiO}_{2}-\mathrm{SiMoA}$ having a high conductivity than Nafion membrane. In this case, the role of and $\mathrm{SiO}_{2}$ as HPA immobilizer so HPA would be exist fix in the Nafion polymer matrix.

\subsection{Heteropolyacid (HPA).}

One type of HPA is phoshotungstic acid $\left(\mathrm{H}_{3} \mathrm{PW}_{12} \mathrm{O}_{40}\right.$, PWA) which has been successfully used as filler of electrolyte membranes used in PEMFC and can also be a catalyst for the reaction of $\mathrm{CO}$ and $\mathrm{O}_{2}$ to produce $\mathrm{CO}_{2}$. $\mathrm{CO}$ is always in small amounts in the hydrogen fuel. Structure of molecule HPA consists of complex Bronsted acid that joined with polyoxomethalate anion (heteropoly anion) in which the HPA has the basic bond structure of metal-oxygen for forming octahedral units. Such composition is known as the Kegin composition of heteropoly anion.

FTIR analysis results show difference of the bond among oxygen atoms in the HPA component. The difference of the bond is shown by the spectrum peaks at different wave number. Bonding of phosphate and oxygen $\left(\mathrm{P}-\mathrm{O}_{\mathrm{a}}\right)$ is indicated by the occurrence of spectral peaks at wave number of $\left(1079 \mathrm{~cm}^{-1}\right)$ meanwhile the bond of tungstic and oxygen is shown by $\mathrm{W}-\mathrm{O}_{\mathrm{b}}-\mathrm{W}$ (edge-shared octahedral of Kegin units) a sign by peak at wave number of $\left(893.09 \mathrm{~cm}^{-1}\right)$ (Ramani et al, 2005). 

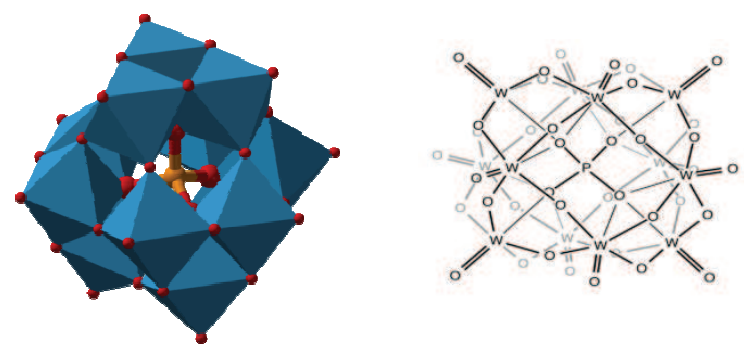

Fig. 7. Kegin structure of atomic oxygen in the $\mathrm{H}_{3} \mathrm{PW}_{12} \mathrm{O}_{40} \cdot 6 \mathrm{H}_{2} \mathrm{O}$ (Irene et al., 2009; Bielanski \& Lubanska, 2004).

Peak of the $\mathrm{W}-\mathrm{O}_{\mathrm{b}}-\mathrm{W}$ is occurred at the wave number of $821 \mathrm{~cm}^{-1}$. The $\mathrm{W}-\mathrm{O}_{\mathrm{d}}-\mathrm{W}$ (terminal oxygen) peak is occurred at the wave number of $981.81 \mathrm{~cm}^{-1}, \mathrm{~W}-\mathrm{O}_{\mathrm{c}}-\mathrm{W}$ (corner shared octahedral of Kegin units) is occurred at wave number of $765 \mathrm{~cm}^{-1}$. HPA crystal consists of anions, cations surrounding the anions are $\mathrm{H}^{+}, \mathrm{H}_{3} \mathrm{O}^{+}$or ion $\mathrm{H}_{5} \mathrm{O}_{2}{ }^{+}$ion and crystal water. Crystal water can be separated by heating. The water release process which can be reversed can be seen by the change in crystal volume. In contrast to the system established by the zeolyte, the HPA Kegin structure is easy to move (mobile). Water and all polar solvents can enter and leave the HPA crystal. HPA crystal properties is a very important as a difference phase catalyst. Solid HPA is acidic which stronger than the solid acid such as $\mathrm{SiO}_{2}, \mathrm{Al}_{2} \mathrm{O}_{3}$, $\mathrm{H}_{3} \mathrm{PO}_{4}-\mathrm{SiO}_{2}, \mathrm{HX}, \mathrm{HY}$, or zeolyte. HPA is very stable at high temperature. The decomposition temperature of the $\mathrm{PW}, \mathrm{SiW}$, PMo and SiMo, respectively, are $465^{\circ} \mathrm{C}, 445^{\circ} \mathrm{C}, 375^{\circ} \mathrm{C}$ and 350 ${ }^{\circ} \mathrm{C}$. Decomposition is occurred because of the loss of acid properties.

\subsection{Silica dioxide $\left(\mathrm{SiO}_{2}\right)$}

Silica in the form of organo-silica tetraethylorthosilicate (TEOS) is more often used as precursors of inorganic materials to modify the Nafion membrane as compared with titanium (Ti) or zirconium $(\mathrm{Zr})$. Viewed from the rate of hydrolysis and condensation reactions, the silica alcoxide is easier to control compared with titanium isopropoxide and zirconium alcoxide (Ramani, et. al. 2006). Zirconium is very reactive so to control the reaction requires the inhibitor component (Show et al., 2006; Ramani et al., 2004).

Tetraethylorthosilicate (TEOS) or $\mathrm{Si}\left(\mathrm{OC}_{2} \mathrm{H}_{5}\right)_{4}$ is the component that has four groups of ligand. Ethoxide $\left(\mathrm{OC}_{2} \mathrm{H}_{5}\right)$ is a ligand that reacts easily through hydrolysis and condensation reaction using water in an acid environment, alkaline or neutral.

\subsection{Parameters that influence the properties of Nafion-inorganic composite membrane} Composite membrane properties are affected by many factors, especially inorganic content, methods and conditions that determine the physical-chemical properties and electrochemical properties of the membrane. Physics-chemical properties include microstructure, heat resistance, mechanical resistance, morphology and structure of chemical bond. Electrochemical properties include conductivity, membrane permeability to gas, ion exchange capacity (IEC), and water uptake rate (WUR) (Ramani et al., 2004).

\subsubsection{Effect of the chemical properties to the micro structure of composite membrane}

The physical-chemical properties of organic and inorganic component strongly influenced to the micro structure and electrochemical property of resulted composite membrane. Due 
to the chemical and physical properties of component determines the interaction between the component in the reaction system especially the kind of bonding between the both components. In the synthesis of organic-inorganic composite, there are two types of bonding occurred, i.e. physical bonding and chemical bonding. The physical bonding is weak, for example, van der Wals bonding and moment dipole bonding. The composite membrane resulted by physical bonding usually easy to form inhomogeneous phase because aggregate forming between inorganic particles and the aggregate will deposit and separated from its organic phase. The composite membrane which is synthesized by chemical bonding has a strong bonding between both components for example by covalent or electrostatic bonding and the interaction between components is strong and homogenous. The strong bonding may prevent of forming aggregate of inorganic particles so the phase separation between both components does not occur and produce the composite with homogenous structure. Resulted membrane by chemical bonding, beside having a nano composite structure, it also has high mechanical resistance (Ramani et al., 2005).

In special case for the synthesis the composite membrane using sol-gel process, it needs the basic component from metaloid group, i.e. $\mathrm{Si}, \mathrm{Ti}, \mathrm{Zr}, \mathrm{Al}$ in the form of organometallic because the metalloid component in the form of organometallic easy to hydrolyze with water and alcohol to produce silanol. Where the silanol may react with inorganic component via chemical bonding (Mauritz, 1998). The component resulted from hydrolysis reaction then is condensed to produce inorganic polymer matrix. Then cross link bonded inorganic polymer matrix with organic polymer so the interaction of both components is strong in the form of cross link bond structure between organic polymer chain and inorganic chain. Meanwhile, to increase conductivity, it needs strong acid, such as heteropoly acid (HPA), i.e. PWA, SiWA, $\mathrm{WO}_{3}$ and SiMoA. In this research, the metalloid is used as a immobilizer of acid component, i.e. PWA, by electrostatic bonding between PWA ion and $\mathrm{OH}$ group of silanol, so PWA may stable in the matrix of Nafion polymer. Silanol also binds with $\mathrm{SO}_{3} \mathrm{H}$ cluster of Nafion by hydrogen bond (Haobold et al., 2001; Bhure et al., 2006). Hydrogen and electrostatic bonds among the three components are desired may produce the composite that interaction between both component in the molecule level so may prevent the aggregate formation of inorganic component and prevent separation of organic-inorganic phase. Then produce homogenous composite membrane with have the nano scale structure. The reaction mechanism of silanol, PWA and $\mathrm{SO}_{3} \mathrm{H}$ are present bellow.

Hydrogen bonding occurs between silanol group and sulphonate molecules of Nafion when electrostatic bonding occur between the silanol and PWA ion. The reason of using tetraetoxiortosilicate (TEOS) as a silicate source is because TEOS reactivity is controllable at low temperature condition and it cheaper than titanium and zirconium and easily provided makes TEOS is used as PWA immobilizer in the organic-inorganic composite membrane.

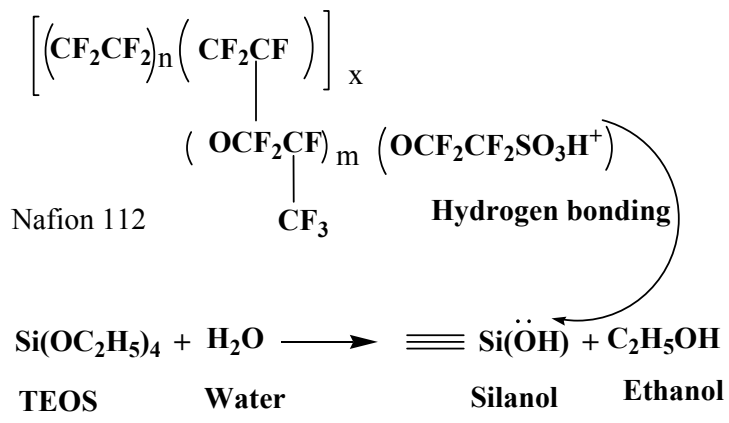




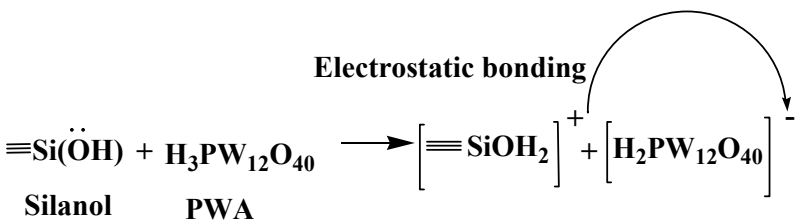

\subsubsection{Effect of solvent properties to the properties of composite membrane}

The structure of the composite strongly depend to the properties of solvent used in the synthesis. In the synthesis, organic-inorganic composite membrane may use non polar, polar protic or polar aprotic solvent, depends on the polarity of the inorganic-organic component. For polar organic component, it may use protic polar or aprotic polar solvent. The protic polar is a polar solvent and produces hydroxyl $\left[\mathrm{OH}^{-1}\right]$ ion in the solution. When the aprotic polar is polar solvent, it does not produce hydroxyl ion in the solution. Examples of protic polar are of alcohol group, and the aprotic solvent such as dimethyl formamide (DMF), dimethyl sulphoxide (DMSO), dimethyl acetamide (DMAc) and tetra hydrofurant (THF). Basic choose of solvent properties is based on consideration that the reaction between organic and inorganic components takes place. Specifically in the synthesis of organicinorganic composite membrane using Nafion as an organic component and TEOS-PWA as an inorganic component, it is inappropriate to use polar protic solvent, because its produces hydroxyl ion which may be interact with $\mathrm{SO}_{3} \mathrm{H}$ of the Nafion. When the interaction occur between sulphonate group with hydroxyl $\left[\mathrm{OH}^{-1}\right]$ from the solvent, the synthesis between sulphonate and $\mathrm{SiOH}$ does not occurred and the separation of organic phase (Nafion) and inorganic phase (SiOH-PWA) takes place. The second consideration is the solvent boiling point. The solvent is selected to have a boiling point almost the same as the glass transition temperature $\left(\mathrm{T}_{\mathrm{g}}\right)$, instead of its organic component (Ramani et al., 2005). For example, the glass transition temperature of Nafion is in the range of $130{ }^{\circ} \mathrm{C}$ to $140{ }^{\circ} \mathrm{C}$, depends on water content in the membrane. DMF solvent has the boiling point of $153{ }^{\circ} \mathrm{C}, \mathrm{DMSO}$ is of $189{ }^{\circ} \mathrm{C}$, THF is of $66^{\circ} \mathrm{C}$ and DMAc is of $166^{\circ} \mathrm{C}$. Selected to be DMF because of having the boiling point closer to $\mathrm{T}_{\mathrm{g}}$ than Nafion so DMF is the solvent used. The DMF have been used by many researchers in the synthesis of organic-inorganic composite membrane (Staiti et al., 2002; Ramani et al., 2005; Shao et al., 2004).

\section{Preparation of Nanocomposite Nafion-SiO ${ }_{2}$-PWA membrane by using sol- gel method}

Fabrication method is a critical factor that influence the resulting composite membrane structure. To produce a composite membrane having the desired properties requires the appropriate selection method. The method to synthesize the Nafion/metal alcoxide/HPA composite membrane will follow the given process, namely, the impregnation, the dispersion and finally the in-situ sol-gel method.

This research is carried out to produce Nafion- $\mathrm{SiO}_{2}-\mathrm{PWA}$ membraneby using sol-gel methode using $5 \%$ Nafion solution as organic material in the isopropylalcohol (IPA) solvent. Nafion solution is left in the fume hood to evaporate the solvent and produce the solid Nafion. Further the solid Nafion is dissolved in dimethylformamide (DMF) it becomes 5 wt.\% Nafion solution in DMF solvent. The next step is mixing the tetraetoxyortosilica $\left(\mathrm{Si}\left(\mathrm{OC}_{2} \mathrm{H}_{5}\right)_{4}\right.$, TEOS) and phosphotungstic acid $\left(\mathrm{H}_{3} \mathrm{PW}_{12} \mathrm{O}_{40}, \mathrm{PWA}\right)$ to Nafion-DMF solution 
and stirred for 6 hours to produce homogeneous solution. Then the solution is poured into a Petri dish and left in the room condition during 24 hours to release trapped air bubbles. The membrane in the form of a thin layer is carried out by heating the solution in an oven at a temperature of $80^{\circ} \mathrm{C}$ so that all the solvent evaporates and the process was continued at a temperature of $140{ }^{\circ} \mathrm{C}$, to produced a transparent membrane. The resulting membrane removed from the dish by way of boiling it in the water. After that, the membrane is washed using $0.5 \mathrm{M}$ sulfate acid solution at a temperature of $80^{\circ} \mathrm{C}$ for one hour, washed in water at a temperature of $100{ }^{\circ} \mathrm{C}$ and washed again in $3 \%$ of hydrogen peroxide solution at a temperature of $80{ }^{\circ} \mathrm{C}$ for one hour and washed again in water until the rinsed water becoming neutral then dried at room temperature and then dried at a temperature of $80{ }^{\circ} \mathrm{C}$ in vacuum. Furthermore, the physical-chemical properties are analyzed using FTIR, TGA, SEM, TEM, UV-VIS, EDX, XRD, WUR and FCTS. The membrane produced then is given the name: NS10W, NS15W, NS20W.

\section{Result and discussion}

Nafion- $\mathrm{SiO}_{2}$-PWA composite membrane is a mixture of three components, namely Nafion, TEOS and phosphotungsten acid. Nafion is the main material of organic compound membrane and the PWA is an inorganic compound material that is added to the polymer to increase the Nafion conductivity. TEOS is immobilizer in order PWA is not to be separated from the Nafion polymer matrix. Preliminary analysis had been conducted to determine the maximum content of PWA in the silica pores. This step is done to ensure that the PWA cannot be separated from the Nafion- $\mathrm{SiO}_{2}-\mathrm{PWA}$ mixture. Analysis is performed using solgel method by mixing TEOS solution, water and methanol with the mole ratio (TEOS: water: methanol = 1:4:4). The location of PWA Chrystal in the $\mathrm{SiO}_{2}$ surface is determine using X-ray spectrometer (XRD). XRD analysis is also carried out on $\mathrm{SiO}_{2}$ crystal and PWA, in the pure state to compare the XRD pattern neither the PWA Chrystal is in the silica pore or in silca surface. The result of XRD analysis to the mixture of $\mathrm{SiO}_{2}-\mathrm{PWA}$ shows that the maximum PWA content in the silica in the wt. ratio of $\mathrm{PWA} / \mathrm{SiO}_{2}$ is 0.45 .

The Nafion- $\mathrm{SiO}_{2}-\mathrm{PWA}$ composite membrane is synthesized from Nafion, TEOS and PWA solution using the maximum ratio of PWA:TEOS 0.4. Preliminary analysis to determine the temperature of solvent evaporation, annealing temperature and annealing time needs to be done to produce a composite membrane which has transparent properties. Physics-chemical properties are analyzed using SEM, EDX, FTIR, TGA, UV-VIS, WUR and TEM.

\subsection{Determination of solvent evaporation temperature}

Solvent evaporation temperature is influence to the structure of resulted composite membrane because the temperature determines the reaction rate between the functional groups of organic and inorganic component. Specifically in the synthesis of $\mathrm{Nafion}^{-\mathrm{SiO}_{2}-}$ PWA composite membrane, at a low temperature, the reaction rate is very slow so it may not provide silanol molecule in the adequate amount to react with sulphonate and PWA ion. The research that had been carried out by (Ramani et al., 2005; Staiti et al., 2001; Zoppi et al., 1998) found that evaporation temperature of the solvent is different depends on the properties of reactant and solvent used, where part of them is used at low temperature (Zoppi et al., 1998), intermediate temperature (80 to 100) ${ }^{\circ} \mathrm{C}$ (Ramani et al., 2004), and high temperature above $100^{\circ} \mathrm{C}$ (Staiti et al., 2002) or closed to boiling point of the solvent. Effect of evaporation temperature on the composite membrane properties has not been 
investigated yet. Therefore, based on previous research results it can be concluded that there are three temperature levels of evaporation of the solvent, i.e. the evaporating temperature that far below the solvent boiling point, closed to solvent boiling point and above the solvent boiling point. Determining of solvent evaporating temperature is always related to solvent function itself in order to increase the reaction rate among involved components in the reaction. It is recommended that the solvent does not evaporate before the reaction taking place because one of solvent function is shortening the distance between reacted molecules so the reaction takes place faster. If the solvent evaporates before the reaction taking place then the reaction will not be occurred, instead the separation of organicinorganic phase is occurred.

In this experiment solvent evaporation temperature is changed between the temperature $\left(30^{\circ} \mathrm{C}, 80^{\circ} \mathrm{C}\right.$ and $140{ }^{\circ} \mathrm{C}$ ) so that all the solvent evaporate, and the solid membrane in the form of thin film is produced. Then, the membrane is heated at a temperature of $140{ }^{\circ} \mathrm{C}$ for 10 hours so as to produce the Nafion-SiO $2-\mathrm{PWA}$ composite membrane. The characterization result directly shows that the resulted membrane at solvent evaporation temperature of $80^{\circ} \mathrm{C}$ has transparent property, meanwhile the resulted membrane at the solvent evaporation temperature of $30{ }^{\circ} \mathrm{C}$ and $140{ }^{\circ} \mathrm{C}$ are translucent. Therefore, based on that observation, it can be concluded that the best solvent evaporation temperature is $80^{\circ} \mathrm{C}$. The appearance of transparency shows that the resulting composite membrane has a homogeneous structure and does not apply separation of organic-inorganic phase (Zulfikar, 2005). The appearance of transparency also indicates that the composite membrane structure is already in the nanometer scale.

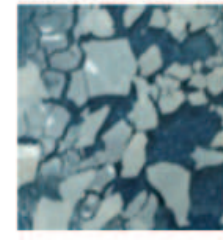

a

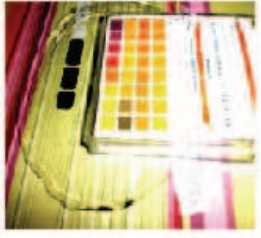

b

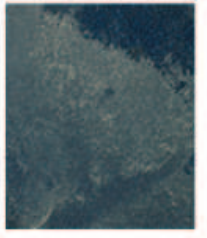

c

Fig. 8. Appearance of the resulted composite membrane using sol-gel method at solvent evaporation temperatures of (a) $30^{\circ} \mathrm{C}$, (b) $80^{\circ} \mathrm{C}$ and (c) $140{ }^{\circ} \mathrm{C}$ (Mahreni et al., 2009)

Optically transparency is used as the initial measurement on the homogeneous phase formation from organic-inorganic phase. As can be seen in Table 1, the resulted composite membrane at low evaporation temperature of $30^{\circ} \mathrm{C}$ has the translucent characteristic and cracked and the obtained composite membrane at the temperature of $80^{\circ} \mathrm{C}$ has properties of transparent and does not crack. The membrane can easily forms a thin film, meanwhile at the high evaporation temperature of $140{ }^{\circ} \mathrm{C}$ it produces the porous composite membranes and uneven thickness. Therefore, it can be concluded that the circumstances the best solvent evaporation temperature is $80^{\circ} \mathrm{C}$. Similar results were obtained in the synthesis of Nafion$\mathrm{SiO}_{2}$ composite membrane that was reported by (Adjemian et al., 2001). This can be explained that the solvent evaporate temperature is very influential to the formation reaction rate of silanol group $(\mathrm{SiOH})$ resulted through the hydrolysis reaction of TEOS in Nafion-TEOS-PWA solution.

Silanol group compound is necessary to react with sulfonic functional groups of the Nafion which is by hydrogen bonding (Haobold et al., 2001) and by reaction with a group of PWA 
ions through electrostatic interactions (Bhure et al., 2008). Thus, chemical interaction can apply to among organic compound (Nafion), inorganic compound (silanol group) and PWA. Chemical interaction among all of these compounds will prevent phase separation among all of the three compounds and produces a composite having a strong bond among the existing components in the system and is homogeneous. At low temperatures, the possibility of the formation of silanol group is slow so chemical interaction among the three compounds is not applicable and possible occurs the phase separation. Phase separation among the three compounds produces membrane that has opaque appearance as shown in Fig. 8 (a). Therefore, the higher the temperature, the faster the reaction and the formation of silanol group compounds is also faster.

If viewed from the solvent evaporation rate, the higher the temperature, the faster the solvent evaporation. The solvent acts as a medium that can increase the collision factor between the reacted reactants. By the existence of solvent, reaction rate becomes faster and prevent the formation of inorganic particle aggregate involved in the reaction. When the solvent evaporates before occurring the reaction between Nafion-Silanol group compound and silanol group-ion PWA, reaction the three components will be slower due to the solvent medium has evaporated and the possibility of occurring the phase separation by inorganic particles that form aggregates and settles. Aggregate formation led to the greater particle size and heavier, therefore the deposition process can not be circumvented. Deposition of inorganic particles causes separation of organic-inorganic phase and causes the resulted membrane being translucent. At temperature of $80{ }^{\circ} \mathrm{C}$, hydrolysis reaction of TEOS compound is occurred faster so it can form silanol group bonds immediately. Silanol group is adequately available to form bonds with the sulfonic group and PWA ions to produce a Nafion- $\mathrm{SiO}_{2}$-PWA composite. Rapid interaction between these three materials can avoid the occurance of phase separation between inorganic compounds and organic compounds that eventually produces a homogeneous composite. Hydrogen bonds between the silanol group and sulfonic and electrostatic interactions between the silanol group and PWA ions encourage the formation of membrane in the nanometer level because the lasting interaction phase is in molecule level. This can be analyzed through the membrane properties that is synthesized at a solvent evaporation temperature of $80^{\circ} \mathrm{C}$ that are transparent as shown in Fig. 8 (b). Meanwhile, at the high solvent evaporates temperature of $140^{\circ} \mathrm{C}$, the increase in solution viscosity is very fast which makes resistance of interaction between the silanol group compound and sulfonic group and PWA becomes larger. This condition also causes occurring the phase separation and the characteristics of the resulting composite membrane at high evaporation temperature is also translucent and porous as shown in Fig. 8 (c) and Table 1.

\begin{tabular}{ccc}
\hline $\begin{array}{c}\text { Solvent evaporation } \\
\text { temperature }\end{array}$ & Physical characteristic & Other visual observation \\
\hline $30{ }^{\circ} \mathrm{C}$ & Translucent & Crack \\
$80 \circ \mathrm{C}$ & Transparent & Flat \\
$140{ }^{\circ} \mathrm{C}$ & Translucent & Porous \\
\hline
\end{tabular}

Table 1. Physical observation of Nafion-SiO ${ }_{2}-\mathrm{PWA}(\mathrm{NS} 15 \mathrm{~W})$ composite membrane at various evaporation temperatures of solvent on constant annealing temperature of $140{ }^{\circ} \mathrm{C}$ and annealing time of 10 hours. 
By the analysis result shown in Fig. 8, it can be concluded that the solvent evaporation temperature of resulting composite membrane which is transparent and homogeneous is at a temperature of $80{ }^{\circ} \mathrm{C}$. Meanwhile the resulting composite membrane at the solvent evaporation temperature of $30^{\circ} \mathrm{C}$ and $140^{\circ} \mathrm{C}$ is not homogeneous and the phase separation between organic and inorganic is also occurred.

\subsection{Determination of annealing temperature and time}

In this case, the temperature factor must be adjusted to the properties of organic materials, especially glass transition temperature $\left(\mathrm{T}_{\mathrm{g}}\right)$ of the Nafion. At the temperature that closed to the glass transition temperature of the organic component. Meanwhile above the glass transition temperature it is possible to change of physical and chemical properties of its organic component and it will be able to damage the Nafion structure. So needs to be studied further in order to obtain the appropriate casting (solvent evaporation and annealing) temperature, which can produce membranes that are not fragile, easily formed into a thin film so easy to use as the electrolyte in the PEMFC (Ramani et al., 2005).

Annealing is an important stage of the process especially in the synthesis of composite membranes, the field of materials and metallurgy. By this process, material properties such as hardness and strength may change due to changes in the microstructure of these materials (Jesse et al., 2007). Annealing process is usually done by heating at a certain temperature adjusted to the desired material properties, followed by cooling slowly. According to the thermodynamic, annealing is occurred because the absorption of atoms in a solid material made of solid material more towards the equilibrium state. In this state, an amount of heat is needed to provide power that may break the bond to have atomic absorption quickly.

Annealing process commonly used in the synthesis of semiconductor materials, where the process is carried out on thin silica and varnish materials usually boron, phosphorus or arsenic (Ar). Varnish materials can absorb into the crystal lattice at a particular location and can produce a change in the electrical properties of semiconductor materials.

The transparency of the composite membrane is obtained from annealing treatment for 10 hours at a temperature of $140{ }^{\circ} \mathrm{C}$. Annealing in the synthesis of composite membranes Nafion-SiO2-PWA is the process whereby occurring the strengthening of organic polymer and inorganic polymer tissues. Polymerization occurs in organic materials where the monomer (ionomer) Nafion is joined with other monomers to form a series of polymer chains.

\begin{tabular}{ccccc}
\hline $\begin{array}{c}\text { Annealing } \\
\text { Temperature } \\
\left({ }^{\circ} \mathrm{C}\right)\end{array}$ & $\begin{array}{c}\text { Vaporization } \\
\text { temperature } \\
\left({ }^{\circ} \mathrm{C}\right)\end{array}$ & $\begin{array}{c}\text { Annealing time } \\
(\text { hour })\end{array}$ & $\begin{array}{c}\text { Membrane } \\
\text { property }\end{array}$ & $\begin{array}{c}\text { Other visual } \\
\text { observation }\end{array}$ \\
\hline 80 & 80 & 10 & Translucent & Flat \\
100 & 80 & 10 & Translucent & Flat \\
140 & 80 & 10 & Transparent & Flat \\
\hline
\end{tabular}

Table 2. Physical observations of Nafion-SiO2-PWA (NS15W) composite membrane at various annealing temperatures.

Meanwhile, polymerization also applies to the inorganic component of the silanol group compounds $(\mathrm{SiOH})$ who joined the cluster of other silanol group to form a silane bond (Si$\mathrm{O}-\mathrm{Si}$ ). The second polymerization process of organic-inorganic compounds run 
simultaneously to form a cross-linking structure and during the polymerization process will be occurred the reaction between the silanol group-sulfonic group and silanol group-ion of PWA throughout the process. The result of the three components reaction is expected to be the composite compounds which are arranged through inorganic polymer chain and organic polymers that cross-linked and forming organic-inorganic hybrid polymer tissue as predicted in Fig. 9.

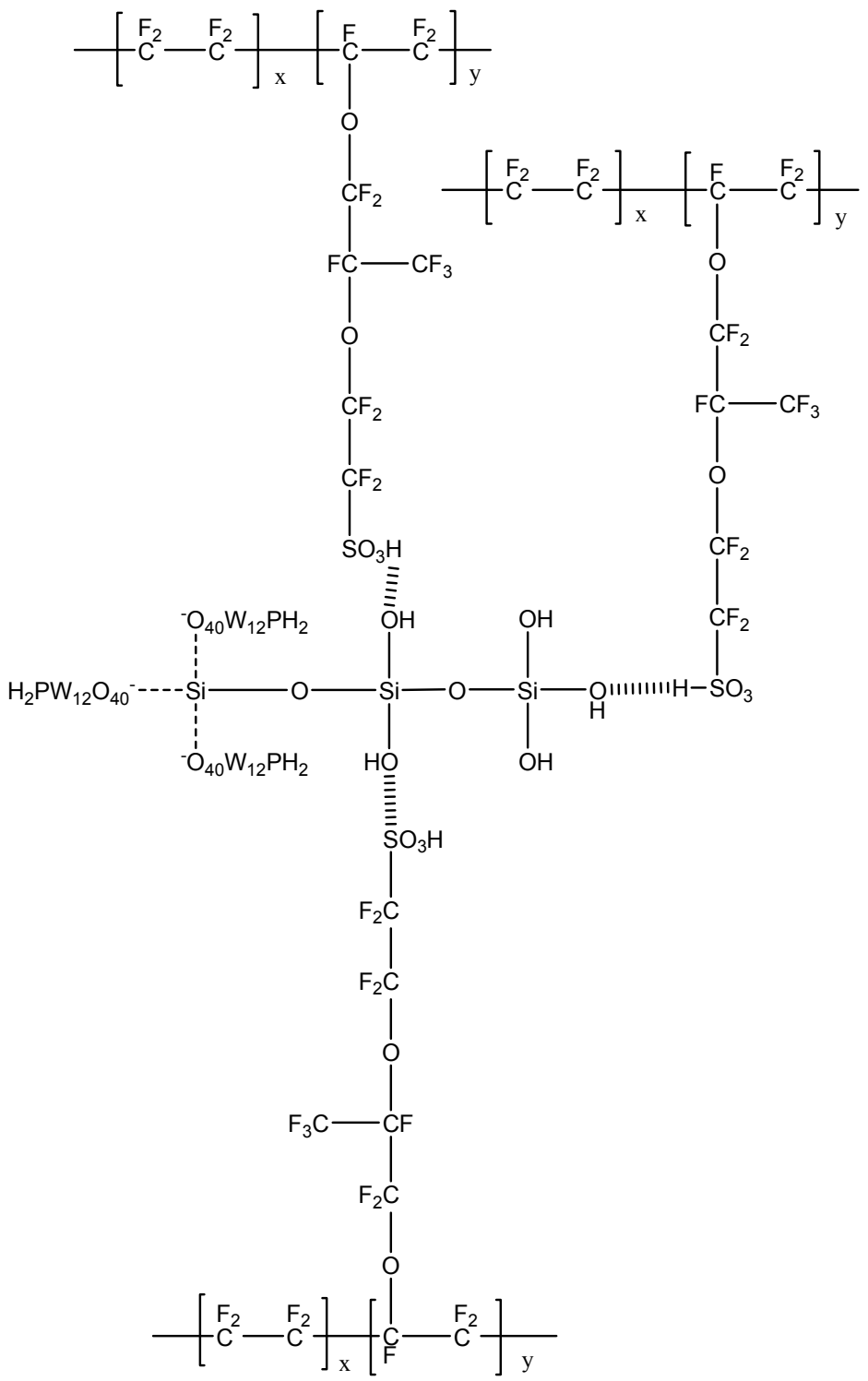

Fig. 9. Prediction of Nafion- $\mathrm{SiO}_{2}-\mathrm{PWA}$ composite membrane molecule structure 


\subsection{Effect of ratio of TEOS-PWA/Nafion to the physical-chemical properties of the Nafion-SiO 2 -PWA composite membrane}

Inorganic components are hygroscopic and have high conductivity can be added to the Nafion membrane with the aim to increasing the water uptake rate of the membrane. It is expected that water diffusion rate through the membrane increase with inorganic material content.

The effect of inorganic material content can be seen from the microstructure and mechanical strength of the membrane. The higher content of inorganic components in the composite membrane, the higher mechanical strength, but when the inorganic content to be raised, the membranes become brittle. The Nafion-SiO 2 composite membrane with $\mathrm{SiO}_{2}$ content higher than $30 \mathrm{wt}$. \% produces a brittle composite membrane so cannot be used to be formed into thin film (Ramani et al., 2004).

The parameter studied is the influence of the TEOS:Nafion ratio on physics-chemical properties of the composite membrane. The ratio (weight/weight) ranges of TEOS:Nafion used are 0.1 (NS10W); 0.15 (NS15W) and 0.2 (NS20W). The physical-chemical properties is analyzed using SEM, TGA, FTIR, EDX and UV-VIS. The result of direct observation of the composite membrane is obtained on solvent evaporation temperature of $80^{\circ} \mathrm{C}$, annealing temperature and time are respectively of $140^{\circ} \mathrm{C}$ and 10 hours and the mixture ratio of PWA:TEOS is 4:10 (weight/weight) and shows the resulted $\mathrm{Nafion}-\mathrm{SiO}_{2}-\mathrm{PWA}$ membrane is transparent. Analysis result is found that when the ratio (TEOS-PWA):Nafion in the composite membrane increases, value of water uptake rate and thermal resistance also increases. Dissociation temperature of a sulfonic groups of pure Nafion membrane is 323.20 ${ }^{\circ} \mathrm{C}$ when the dissociation temperature of the Nafion- $\mathrm{SiO}_{2}-\mathrm{PWA}$ membrane type NS10W, NS15W and NS20W respectively, are $353.53{ }^{\circ} \mathrm{C} ; 368.75^{\circ} \mathrm{C}$; and $348{ }^{\circ} \mathrm{C}$.

The water water uptake rate of pure Nafion membrane is $26.52 \mathrm{wt} . \%$ compared to water water uptake rate with the Nafion- $\mathrm{SiO}_{2}-\mathrm{PWA}$ composite membrane type NS10W, NS15W and NS20W respectively, are $30.25 \%$; $33.43 \%$ and $32.72 \%$ by weight. Thermo gravimetric analysis results also show that the content of inorganic residue components of $\mathrm{P}, \mathrm{Si}$ and $\mathrm{W}$ in the composite membrane NS10W, NS15W and NS20W are respectively $2.31 \mathrm{wt}$. \%, $2.61 \mathrm{wt} . \%$ and $6.16 \mathrm{wt} . \%$. The surface structure and the cross sectional of all the resulting composite membrane is homogeneous. The elemental analyze result of the $\mathrm{P}, \mathrm{Si}$ and $\mathrm{W}$ components are bound to the Nafion polymer matrix. Analysis of XRD shows the components of P, Si and W are in all the resulting composite membrane and can be concluded that the inorganic components added into the Nafion structure such as Si (silica), P (phosphorus) and W (tungstic) cannot be separated even though the membrane is washed using a solution of weak acids and bases.

\subsection{Physical observations}

Optical sighting is an acceptable method and appropriate in approximation of distribution levels of inorganic phase in the organic polymer matrix and an easy method to determine the distribution of organic-inorganic phase in polymer matrix for organic-inorganic composite materials. If the composite material is transparent, it means that the inorganic phase is well-dispersed in nano-scale in the polymer matrix and formed phase equally between the organic polymer and it inorganic. If phase separation occurs, the composite membrane formed will look blur and not transparent. This situation will affect themechanical strength of the resulting membrane (Zulfikar, 2005). The physical properties of synthesized composite membranes at the solvent evaporation temperature of $80^{\circ} \mathrm{C}$, the 
annealing temperature of $140^{\circ} \mathrm{C}$, annealing time of 10 hours with the ratio of TEOS:Nafion of $0.1 ; 0.15 ; 0.2$ and 0.3 (weight/weight) and were labeled as NS10W, NS15W, NS20W and NS30W respectively present in Table 3 show that all of the resulting composite membranes are transparent.

\begin{tabular}{lcc}
\hline \multicolumn{1}{c}{ Membrane type } & Physical property & Space property \\
\hline N112 & Transparent & Flat (no crack) \\
NS10W & Transparent & Flat (no crack) \\
NS15W & Transparent & Flat (no crack) \\
NS20W & Transparent & Flat (no crack) \\
NS30W & Transparent & Crack \\
\hline
\end{tabular}

Table 3. The physical properties of Nafion membrane (N112) and composite membranes synthesized in the solvent evaporation temperature of $80^{\circ} \mathrm{C}$, annealing temperature of $140^{\circ} \mathrm{C}$, and annealing time of 10 hours.

These show that the phase separation is not formed and the inorganic phase distribution is uniform on every part of the organic phase in the nano-scale in the organic polymer matrix (Kong et al., 2002). To demonstrate the nanostructures have been formed from the composite membrane, the analysis is done using a UV-VIS to determine the membrane spectrum obtained in percent of emission against the wavelength in the range of between $200 \mathrm{~nm}$ to $700 \mathrm{~nm}$.

\subsection{Observation of transparency of the composite membrane using UV-VIS}

Analysis of the transparency is carried out to distinguish the transparency level of the pure Nafion membrane and NS10W, NS15W and NS20W composite membranes. Analysis is performed using a spectrometer (UV-VIS-NIR-LAMDA-900/10/N102290) in the wavelength range of $200 \mathrm{~nm}$ to $700 \mathrm{~nm}$. UV-VIS produces radiance percentage data (\% T) versus wavelength as presented in Table (4) and Figure (12).

\begin{tabular}{|c|cccc|}
\hline \multirow{2}{*}{$\begin{array}{c}\text { Wavelength } \\
\text { (nm) }\end{array}$} & \multicolumn{4}{|c|}{ Radiance percentage (\%T) } \\
\cline { 2 - 5 } & N112 & NS10W & NS15W & NS20W \\
\hline 700 & 94,243372 & 94,05981 & 93,87149 & 92,86329 \\
600 & 94,032063 & 93,46925 & 93,11725 & 91,45416 \\
500 & 93,804864 & 92,79481 & 92,83312 & 90,25151 \\
400 & 93,154372 & 91,03936 & 91,47739 & 85,71702 \\
300 & 90,881045 & 85,47923 & 88,31753 & 7,963876 \\
200 & 52,93781 & 50,55418 & 47,86428 & 0 \\
\hline
\end{tabular}

Table 4. UV-VIS analysis results on wavelength range of (200 to 700) nm for the N112, NS10W, NS15W and NS20W membranes.

The data of transmission such as those found in Table 4. and Fig. 10 show that if the wavelength is specified, the higher concentrations of inorganic components contained in the composite membrane, emission decreases. The decreasing of emissions is due to the size of inorganic particles become increasingly larger when concentration of inorganic components in the membrane increases (Kukovez et al., 2002; Wang et al., 2007). 
Quantitative relationship between the percent emission and particle size has been conducted by many researchers (Khanna et al., 2005) using empirical equation model that relates among the emission, film thickness and the absorption constant which is expressed by equation 6 (Apparacio et al., 2005; Mahreni et al., 2009).

$$
T=A \exp (-\alpha d)
$$

where $T, A, \alpha, d$, respectively, emission on the maximum absorption $\left(\mathrm{T}_{\lambda \max }\right)$, constant $(\mathrm{A}=$ 1), absorption constant and thickness of the membrane. By using equation (6) and Table (4) with the membrane a thickness is set at $(70 \pm 5) \mu \mathrm{m}$, a for each membrane can be calculated as listed in Table (5).

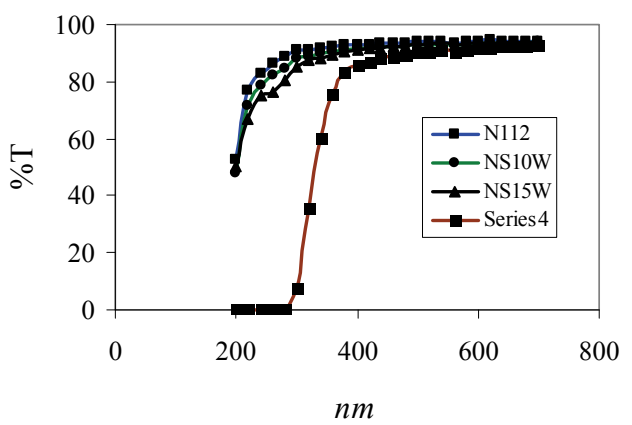

Fig. 10. UV-VIS spectra of N112, NS10W, NS15W and NS20W membranes in transmission (\% T) versus wavelength (nm) (Mahreni et al, 2009).

\begin{tabular}{cccc}
\hline $\begin{array}{c}\text { Membrane } \\
(\mu \mathrm{m})\end{array}$ & $\lambda_{\max }(\mathrm{nm})$ & $\begin{array}{c}\text { Transmission } \\
(\mathrm{T})\end{array}$ & $\begin{array}{c}\mathrm{a} \\
\left(\mathrm{cm}^{-1}\right)\end{array}$ \\
\hline N112 & 200 & 0.529 & 92.22 \\
NS10W & 200 & 0.505 & 97.45 \\
NS15W & 200 & 0.478 & 105.44 \\
NS20W & 300 & 0.079 & 361.53 \\
\hline
\end{tabular}

Table 5. Constants of N112 membrane absorption and composite membranes on the thickness membrane of $70 \mu \mathrm{m}$.

Table 5 shows that when the concentration of inorganic component in a composite membrane increases then the absorption constant of the membrane (a) will increases. By using a model which is written by equation (6), (7) and (8), band gap energy ( $\left.E_{g}\right)$ of composite membrane can be calculated quantitatively.

$$
\begin{gathered}
a h v=D\left(h v-E_{g}\right)^{n} \\
E_{g, \text { nanocrystal }}=E_{g, \text { bulk }}+\frac{\pi^{2} h^{* 2}}{2 R^{2}}\left(\frac{1}{m_{e}}+\frac{1}{m_{h}}\right) \\
h^{*}=\frac{h}{2 \pi}
\end{gathered}
$$


Where $h$ is Plank's constant $\left(6.6 \times 10^{-27} \mathrm{erg} \mathrm{sec}\right), \mathrm{E}_{\mathrm{g}}$ is energy band gap $(\mathrm{eV})$ and $\mathrm{n}$ is a constant for the energy band gap directly or indirectly, $E_{g, \text { nanocrystal, }} E_{g, b u l k}, h, R, m_{e}, m_{k}$ respectively are pure Silica energy band gap $(1.1 \mathrm{eV})$, Plank's constant and the particle size, the electron mass $\left(m_{e}=1.08 m_{0}\right)$ and the mass of the hole $\left(m_{h}=0,56 m_{o}\right)$ of silica particles. The energy band gap is used to calculate the size of inorganic particles in the composite membrane by using equation (8) and (9) (Singh et al., 2006; Xu et al., 2008; Khanna et al., 2005; Mahreni et al., 2009).

The result of UV-VIS analysis of all membranes is shown in Table 5 and Figure 12, N112, NS10W and NS15W membranes have maximum absorption at a wavelength of $200 \mathrm{~nm}$. The percentage of emission membrane of N112, NS10W and NS15W at a wavelength of $200 \mathrm{~nm}$ is $0.529 ; 0.505$ and 0.478 . The maximum absorption of NS20W membrane occurs at a wavelength of $300 \mathrm{~nm}$. At a wavelength of $300 \mathrm{~nm}$, the percentage transmission of NS20W is 0.079. By that information and equation of (6), with $\mathrm{A}=1$ and $70 \mu \mathrm{m}$ of membrane thickness $=0.07 \mathrm{~mm}$, absorption constant of each membrane can be determined and as in Table 5. The energy band gap is calculated using the constant absorption contained in Table 5 and extrapolate curve in Figure 16 in the (Mahreni, 2009), energy band gap can be determined and are in Table 6, along with energy band gap of pure silica reported by (Garrido et al., 2004) as comparison of energy band gap of silica components in the composite membrane ( $\mathrm{E}_{\mathrm{g}}$, nanocomposite) and pure silica $\left(\mathrm{E}_{\mathrm{g}, \mathrm{bulk}}\right)$.

\begin{tabular}{ccc|cc}
\hline & \multicolumn{2}{c}{ This study } & \multicolumn{2}{c}{ Garrido et al., 2004 } \\
\hline Membrane & $\mathrm{E}_{\mathrm{g}}(\mathrm{eV})$ & $\begin{array}{c}\text { Particle diameter } \\
(\mathrm{nm})\end{array}$ & $\mathrm{E}_{\mathrm{g}}(\mathrm{eV})$ & $\begin{array}{c}\text { Particle } \\
\text { diameter }(\mathrm{nm})\end{array}$ \\
\hline NS10W & 2,75 & 2,1 & 2,3 & 2,1 \\
NS15W & 2,5 & 5,13 & 2,11 & 3 \\
NS20W & 2,4 & 5,32 & 1,5 & 6 \\
\hline
\end{tabular}

Table 6. Diameter of $\mathrm{SiO}_{2}$ particles in the NS10W, NS15W and NS20W composite membranes as a function of energy band gap.

Table 6. shows if the content of inorganic components increase in the composite membrane, the particles $E_{g}$ will decrease and the particle diameters will increase. This phenomenon proves that the higher content of inorganic components, the larger particle size that will be formed. This is because the higher concentrations of inorganic components will facilitate the formation of aggregates (Garrido et al., 2004). To measure the real particle diameter of inorganic compounds in the composite membranes, analysis is continued using transmission electron microscopy (TEM).

\subsection{Chemical structure of composite membranes by using FTIR}

Analysis of the chemical structure of composite membranes is conducted using FTIR to investigate the chemical bonding of the composite membrane. Observations were done on the percentage of emission against wave numbers in regions of certain wave number. Spectral peaks depic the type of chemical bonds existing in the sample (Ruichun Jiang et al., 2006; Ramani et al., 2005).

Infrared spectra obtained at the wavelength of (400 to 4000) cm-1 are shown in Figure 4.7 (a to d) in Mahreni, 2009. Such images show that spectral peaks of the composite membrane shift when the content of inorganic component changes. In this figure show the chemical 
reaction between a group of sulfonic- $\mathrm{SiO}_{2}$ and $\mathrm{SiO}_{2}-\mathrm{PWA}$ as indicated by the peak shift in the infrared spectrum of pure Nafion membrane and composite membranes does occur. Vibration of COC bond on NS10W at wave number of $969 \mathrm{~cm}^{-1}$ shifts to lower wave number. Wave number shift may mean that it had been occurred interaction between the sulfonic group and $\mathrm{SiOH}$. The interaction is stronger when the higher content of $\mathrm{SiOH}$ (Ramani et al., 2004; Shao et al., 2003; Je-Deok Kim \& Itaru Honma 2004). Clear explanation in detail have been presented in the previous publication in (Mahreni et al., 2009).

\subsection{TEM analysis}

Fig. 12 (a) to (c) show the cross sectional of NS10W, NS15W and NS20W composite membrane with $60000 \mathrm{X}$ magnification using TEM.

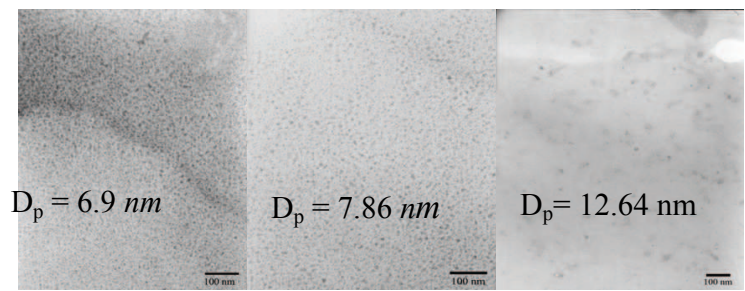

(a)

(b)

(c)

Fig. 11. Cross sectional composite membrane (a) NS10W, (b) NS15W and (c) NS20W with 60,000 X magnification using TEM (Mahreni et al, 2009).

Fig. 11 shows the size of inorganic particles (Si and PWA) in the NS10W, NS15W and NS20W composite membranes, respectively, are 6,9 nm, 7,864 nm and 12,641 nm. Distribution of particles is found there are more in the NS20W membrane than in the NS 10 and NS15W membranes. NS20W membrane particle size found to be larger than the NS10W and NS15W membranes which caused by the agglomeration of particles causes the inorganic particles are in the space of the polymers. $\mathrm{SiO}_{2}$ and the PWA particle sizes in the NS10W and NS15W composite membranes smaller than cluster size of Nafion causes the both particles trapped in the Nafion cluster and make the conductivity of Nafion increases compared to NS20W membrane having a larger particle size than Nafion cluster size. XRD analysis also shows the location of $\mathrm{SiO}_{2}$ and PWA particles contained in the composite membrane.

\section{Application of the composite membran as electrolyte in the PEMFC}

The composite membrane NS10W, NS15W, NS20W and N112 (pure Nafion), was applied as electrolyte in PEMFC.

\subsection{Membrane electrode assemblies (MEA)}

The membrane was sandwiched between the two electrodes (GDE) and then hot pressed at $130{ }^{\circ} \mathrm{C}$ and $70 \mathrm{~atm}$ for $90 \mathrm{~s}$ to obtain membrane electrode assembly (MEA). Single cell of PEMFC consist of the current collector, bipolar plat in both side of MEA. External circuit is equipped to join anode side and cathode side. Flow chart of the membrane application in the PEMFC is depicted by Fig. 12. 


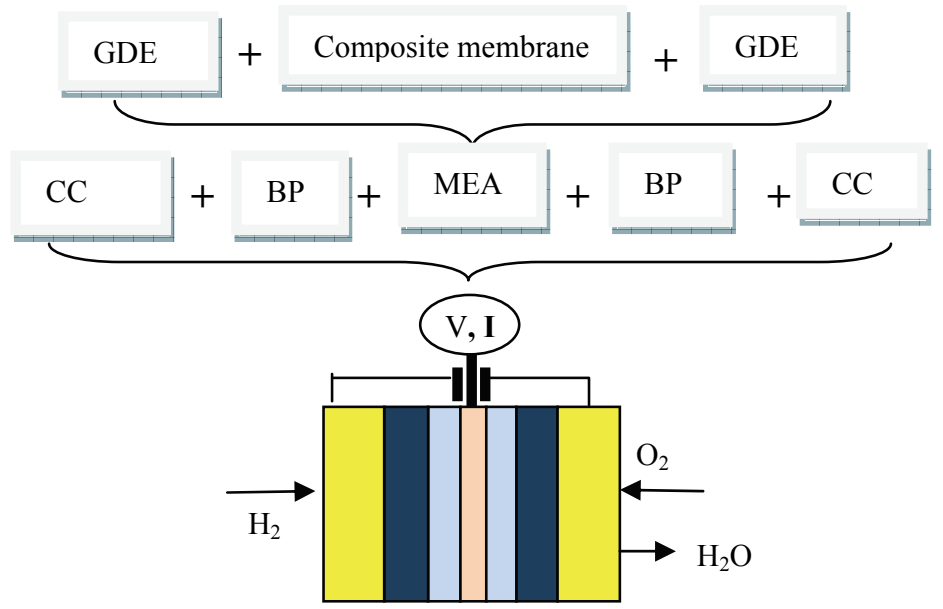

Fig. 12. Flowchart singgle cell test of $\mathrm{Nafion}_{-} \mathrm{SiO}_{2}-\mathrm{PWA}$ membrane as electrolyte of PEMFC.

\subsection{Analysis of the electrochemical properties of composite membranes using FCTS (Fuel cell test system)}

Electrochemical analysis is carried out in order to determine the performance of the composite membranes when it used as electrolytes in PEMFC. To determine the electrochemical properties of the membrane, the membrane is combined with gas diffusion layer (GDL) and catalyst layer (anode and cathode) with a hot pressing method at specified temperature and pressure to produce membrane electrode assemblies (MEA) (Frey \& Linardi, 2004). The single cell of PEMFC is fabricated with sandwich MEA with bipolar plates, the current collector and an external circuit that connect anode and cathode. Single cell is then tested by using fuel cell test station (FCTS). Single cell test is performed to obtain data that represent the performance of the composite membrane as electrolyte at certain operating conditions. The FCTS is equipped with a sensor and controllers of hydrogen fuel and oxygen rate, temperature and pressure.

\section{Conclussion}

The Nafion- $\mathrm{SiO}_{2}$-PWA composite membrane has been produced via sol-gel technique solution phase. The result from the characterization, it can be seen that the composite membrane has the properties of water absorption which is higher than pure Nafion membrane. Thermal resistance property of the composite membrane is higher than the Nafion membrane. The structure of all of composite membranes is homogeneous its diameter is in nanometer level. Results of X-ray observation shows that $\mathrm{SiO}_{2}-\mathrm{PWA}$ particles are inside the cluster of NS10W, NS15W composite membranes, but the particle location is outside of Nafion cluster in the NS20W membrane. Results of FTIR and X-ray energy dispersion observation showing that the silica and tungstic components are bound to the matrix of Nafion polymer prove that the silica and tungstic components added to the Nafion membrane are not be separated from the matrix of Nafion polymer chains. The particles diameter of the composite Nafion-SiO $2-\mathrm{PWA}$ membranes in the range of 7 up to $13 \mathrm{~nm}$. 
Data obtained from FCTS for each type of membrane used as electrolyte in PEMFC are voltage and current density that can be recorded. Membrane performance was analyzed indirectly by analyzing the (V-I) data for each membrane. Every different type of membrane, resulting different (V-I) curve. Therefore, each data reflects the membrane performance when operating parameters such as hydrogen and oxygen rate, temperature, pressure, and other parameters are constant. Analysis with fuel cell test station showed that higher current density was produced by nanocomposite membrane $\left(82 \mathrm{mAcm}^{-2}\right.$ at $0.6 \mathrm{~V}$ for NS15W) than with the Nafion membrane $\left(30 \mathrm{mAcm}^{-2}\right.$ at $\left.0.2 \mathrm{~V}\right)$ at $90 \circ \mathrm{C}$ and $40 \%$ relative humidity.

\section{References}

Ajemian, K.T., Srinivasan, S., Benziger, J. \& Bocarsly, A.B. (2002). Investigation of PEMFC operation above $100{ }^{\circ} \mathrm{C}$ employing perfluorosulfonic acid silicon oxide composite membranes. Journal of Power Sources, 109., 356-364, 0378-7753.

Alberti, G., Casciola, M. D., Capitán, A., Donnadio, R., Narducci, M. Pica and Sganappa, M. (2007). Novel Nafion-zirconium phosphate nanocomposite membranes with enhanced stability of proton conductivity at medium temperature and high relative humidity. Journal of Electrochim Acta, 52., 8125-8132, 0013-4686.

Aparacio, M., Castro, Y., Duran, A. (200). Synthesis and characterization of proton conducting styrene-co-methacrylate-silica sol-gel membranes containing tungstophosphoric acid. Journal of Solid State Ionics, 176., 333-340, 0167-2738.

Ayad, A., Bouet, J \& Fauvarque, J.F. (2005). Comparative study of protonic conducting polymers incorporated in the oxygen electrode of the PEMFC. Journal of Power Sources, 149., 66-71, 0378-7753.

Bhure, M.H., Kumar, I., Natu, A.D., Chikate, R.C. and Rode, C.V. (2008). Silica with modified acid sites as a solid catalyst for selective cleavage of tertbutyldimethylsilyl ethers. Journal of Catal. Commun. (inpress). 1566-7367.

Bielanski, A.\& Lubanska, A. (2004). FTIR investigation on Wells- Dawson and Keggin type heteropolyacids : dehydration and ethanol sorption. Journal of Molecular Catalysis A: Chemical, 224., 179-187, 1381-1169.

Frey, Th. \& Linardi, M. (2004). Effect of membrane electrode assembly preparation on the polymer electrolyte membrane fuel cell performance. Journal of Electrochimica Acta, 50., 99-105, 0013-4686.

Garrido, B., Lopez, M., Rodriguez, P., Garcia, C., Pellegrino, P., Ferre, R., Moreno, J.A., Morante, J.R., Bonafos, C., Carrada, M., Claverie, A., de Latore, J. and Souifi, A. (2004). Optical and electrical properties of Si-nanocrystals ion beam synthesized in $\mathrm{SiO}_{2}$. Journal of NIM B Beam Interactions With Material \& Atoms, 216., 213-221, 0168583 X.

Genies, C., Mercier, R., Sillion, B., Cornet, N., \& Gebel, G \& M. Pineri. (2001). Soluble sulfonated naphthalenic polyimides as materials for proton exchange membranes. Journal of Polymer, 42., 359-373, 0032-3861.

Gyenge, E.L. (2005). Dimensionless numbers and correlating equations for the analysis of the membrane-gas diffusion electrode assembly in polymer electrolyte fuel cells. Journal of Power Sources, 152., 105-121, 0378-7753.

http:/ /id.images.search.yahoo.com/images...=1239fp284\&sigb=12dgi5ntt\&type=JP G\&.crumb=MxqFT4NeXad 
Hamnet, A. 2003. Direct Methanol Fuel Cell. Dlm. Gregor Hoogers (pnyt.). Fundamental technology and application in the Handbook of Fuel Cells, Vol I., p. 318, England. Wiley \& Sons. Ltd..

Haobold, H.G., Vad, T.H., Jungbluth, H. and Hiller, P. (2001). Nano structure of Nafion a SAXS study. Journal of Electrochim Acta, 46., 1559-1536, 0013-4686.

Irene Colicchio, FeiWen, Helmut Keul, Ulrich Simon, Martin Moeller. (2009). Sulfonated poly(ether ether ketone)-silica membranes doped with phosphotungstic acid. Morphology and proton conductivity. Journal of Membrane Science, 326., 45-57, 63767388.

Jang, S.H., Han, M.G, Im, S.S. (2000). Preparation and characterization of conductive polyaniline/silica hybrid composite prepared by sol-gel process. Journal of Synthetic Metals, 110., 17-23, 0379-6779.

Je- Deok Kim \& Itaru Honma. 2004. Synthesis and proton conducting properties of Zirconia bridge hydrocarbon/phospotungsticacid hybrid materials. Journal of Electrochimica Acta, 49., 3179-3183, 0013-1486.

Jesse, E. Hensley., Douglas Way, J., Steven, F. Dec., Kent, D. Abney. (2007). The effects of thermal annealing on commercial Nafion membranes. Journal of Membrane Science, 298., 190-201, 0376-7388.

Jiang Yu Li \& Sia Nemat- Nasser. (2000). Micromechanical analysis of ionic clustering in Nafion perfluorinated membrane. Journal of Mechanics of Materials, 32., 303-314, 1573-8841.

Khanna, P.K., Narendra Singh., Shobit Charan., Kasi Viswanath, A. (2005). Synthesis of $\mathrm{Ag} /$ polyaniline nanocomposite via an in situ photo-redox mechanism. Journal of Material Chemystri and Physic, 92., 214-219, 0254-0584.

Klein, L.C., Daiko, Y., Apparicio, M., Damag, F. (2005). Method for modfying proton exchange membrane using the sol-gel process. Journal of Polymer, 46., 4504-4509, 0032-3861.

Kong, Y., Du, H., Yang, J., Shi, D., Wang, Y., Zhang, Y. \& Xin, W. (2002). Study on polyimide $/ \mathrm{TiO}_{2}$ nanocomposite membranes for gas separation. Desalination, 146., 49-55, 0011-9164.

Kukovecz, A., Balogi, Z., Konya, Z., Toba, M., Lentz, P., Niwa, S.-I., Mizukami, F., Molnar, A., Nagy, J.B., Kiricsi, I. (2002). Synthesis, characterization and catalytic application of sol-gel derived silica-phosphotungstic acid composites. Journal of Applied Catalysis A: Genera, 228., 83-94, 0926-860X.

Lee, H.S., Kim, H.J., Kim, S.G. \& Ahn, S.H. (2007). Evaluation of graphite composite bipolar plate for PEM (proton exchange membrane) fuel cell: Electrical, mechanical, and molding properties. Journal of Materials Processing Technology, 187-188., 425428,0924-0136.

Mahreni et, A., Mohamad, A.B., Kadhum, A.A.H., Daud, .R.W \& Iyuke, S.E. ( 2009). Nafion/silicon oxide/phosphotungstic acid nanocomposite membrane with enhanced proton conductivity. Journal of Membrane Science, 327., 32-40, 0924-0136.

Mahreni. (2009). Sintesis dan penggunaan membran komposit sebagai elektrolit sel fuel membran penukar proton. Tesis Dr. Falsafah, jabatan Kejuruteraan Kimia dan Proses, Universitas Kebangsaan Malaysia. 
Mauritz, K. A. (1998). Organic-inorganic hybrid materials: perfluorinated ionomers as solgel polymerization templates for inorganic alkoxides, Journal of Materials Science and Engineering C, 6., 121-133, 0921-5093.

Park, Y.S., Hatae, T., Itoh, H., Jang, M.Y., Yamazaki, Y. (2004). High proton-conducting Nafion/calcium hydroxyphosphate composite membranes for fuel cells, Journal of Electrochimica Acta, 50., 595-599, 0013-4686.

Pivovar, B.S. (2006). An overview of electro-osmosis in fuel cell polymer electrolytes.Journal of Polymer, 47., 4194-4202, 0032-3861.

Ramani, V., Kunz, H. R. \& Fenton, J.M. (2005). Stabilized heteropolyacid/Nafion composite membranes for elevated temperature/low relative humidity PEFC operation. Journal of Electrochimica Acta, 50., 1181-1187, 0013-4686.

Ramani, V., Kunz H.R. and Fenton, J.M. (2005). Effect of particle size reduction on the conductivity of Nafion/phosphotungstic acid composite membranes. Journal of Membrane Science, 266: 110-114, 0013-4686.

Ramani, V., Kunz, H.R. \& Fenton, J.M. (2004). Investigation of Nafion/HPA composite membranes for high temperature/low relative humidity PEMFC operation. Journal of Membrane Science, 232., 31-44, 0376-7388.

Ruichun Jiang., Kunz, H. R, Fenton J. M. (2006). Composite silica/Nafion membrane prepared by tetraethoxyorthosilicate sol-gel reaction and solution casting for DMFC. Journal of Membrane Science, 272., 116-124, 0376-7388.

Shao, Z.G., Joghee, P., Hsing, I.M. (2003). Preparation and characterization of hybrid Nafion-silica membrane doped with phosphotungstic acid for high temperature operation of proton exchange membrane fuel cells. Journal of Membrane Science, 229., 43-51, 0376-7388.

Singh, K., Saxena, N.S., Srivastava, O.N., Patidar, D. and Sharma, T.P. (2006). Energy band gap of $\mathrm{Se}_{100-\mathrm{x}} \mathrm{In}_{\mathrm{x}}$ chalcogenide glasses. Chalcogenide Letters, 33., 363-369, 1584-8663.

Smitha, B, Sridar, S., Khan, A. A. (2005). Solid polymer electrolyte membrane for fuel cell application- a review. Journal of Membrane Science, 259., 10-26, 0376-7388.

Staiti, P., Arico, A.S., Baglio, V., Lufrano., Passalcqua, F. E. \& Antonucci, V. (2001). Hybrid Nafion-Silica membranes doped with heteropolyacids for application in DMFC. Journal of Solid State Ionics, 145., 101-107, 0167-2738.

Wang, H.M., Fang, P., Chen, Z. and Wang, S. (2007). Synthesis and characterization of CdS/PVA nanocomposite films. Journal of Surface Science, 253., 8495-8499, 00396026.

Yang, B., Fu, Y.Z. \& Manthiram, A. (2004). Operation of thin Nafion based self-humidifying membrane in proton exchange membrane fuel cell with dry $\mathrm{H}_{2}$ and $\mathrm{O}_{2}$. Journal of Power Sources, 139., 170-175,0378-7753.

Zoppi, R.A. \& S.P Nunes. (1998). Electrochemical impedance studies of hybrids of perfluorosulfonic acid ionomer and silicon oxide by sol-gel reaction from solution. Journal of Analytical Chemistry, 445., 39-45, 1608-3199.

Zulfikar, M.A. (2005). Sintesis dan pencirian membran hibrid tak organik-organik. Tesis Dr. Falsafah, Jabatan Kejuruteraan Kimia dan Proses, Universiti Kebangsaan Malaysia. 


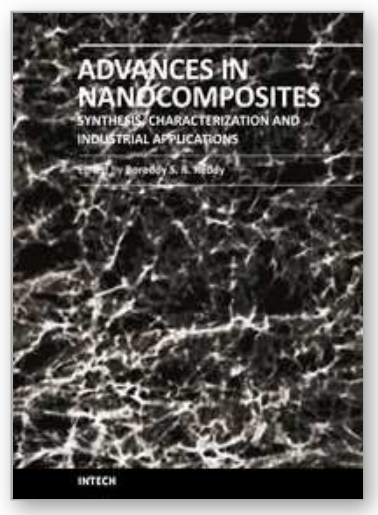

\author{
Advances in Nanocomposites - Synthesis, Characterization and \\ Industrial Applications
}

Edited by Dr. Boreddy Reddy

ISBN 978-953-307-165-7

Hard cover, 966 pages

Publisher InTech

Published online 19, April, 2011

Published in print edition April, 2011

Advances in Nanocomposites - Synthesis, Characterization and Industrial Applications was conceived as a comprehensive reference volume on various aspects of functional nanocomposites for engineering technologies. The term functional nanocomposites signifies a wide area of polymer/material science and engineering, involving the design, synthesis and study of nanocomposites of increasing structural sophistication and complexity useful for a wide range of chemical, physicochemical and biological/biomedical processes. "Emerging technologies" are also broadly understood to include new technological developments, beginning at the forefront of conventional industrial practices and extending into anticipated and speculative industries of the future. The scope of the present book on nanocomposites and applications extends far beyond emerging technologies. This book presents 40 chapters organized in four parts systematically providing a wealth of new ideas in design, synthesis and study of sophisticated nanocomposite structures.

\title{
How to reference
}

In order to correctly reference this scholarly work, feel free to copy and paste the following:

Mahreni, A.B. Mohamad, A.A.H. Khadum and W.R.W. Daud (2011). Nanocomposite Electrolyte for PEMFC Application, Advances in Nanocomposites - Synthesis, Characterization and Industrial Applications, Dr. Boreddy Reddy (Ed.), ISBN: 978-953-307-165-7, InTech, Available from:

http://www.intechopen.com/books/advances-in-nanocomposites-synthesis-characterization-and-industrialapplications/nanocomposite-electrolyte-for-pemfc-application

\section{INTECH}

open science | open minds

\section{InTech Europe}

University Campus STeP Ri

Slavka Krautzeka 83/A

51000 Rijeka, Croatia

Phone: +385 (51) 770447

Fax: +385 (51) 686166

www.intechopen.com

\section{InTech China}

Unit 405, Office Block, Hotel Equatorial Shanghai

No.65, Yan An Road (West), Shanghai, 200040, China

中国上海市延安西路65号上海国际贵都大饭店办公楼 405 单元

Phone: +86-21-62489820

Fax: $+86-21-62489821$ 
(C) 2011 The Author(s). Licensee IntechOpen. This chapter is distributed under the terms of the Creative Commons Attribution-NonCommercialShareAlike-3.0 License, which permits use, distribution and reproduction for non-commercial purposes, provided the original is properly cited and derivative works building on this content are distributed under the same license. 